\title{
The Nature and Theoretical Limits of Adjudicative Formalism in Contemporary Anglo-Saxon Legal Theory
}

\author{
KRISZTINA FiCSOR
}

\begin{abstract}
In this essay, the author attempts to reveal the character and theoretical limits of judicial formalism. Formalism is a normative theory of adjudication which means that it provides determined answers to the question of how judges should decide legal cases. Judicial formalism is related to the view that legal reasoning is a special area of practical reasoning because legal reasoning should rely on reasons and arguments that stem from a limited domain of practical reasons: lawyers should justify legal decisions by relying on the reasons that originate in socalled source-based law. However, one of the tasks of legal theory is to solve the problem of judicial formalism which arises during legal practice. It can often occur that the decision, which follows clearly from the sourcebased law, is unjust or unfair if we take all relevant factors and the wider context of the case into consideration. The theoretical issue is whether judges are allowed to depart from the source-based law and if they are, in what type of cases can they do this. This essay tries to throw light on the theoretical conceptions within which the problem of formalism can be handled, for example, the theory of the nature of law or virtue jurisprudence.
\end{abstract}

Keywords: theory of adjudication, judicial formalism, legal reasoning

\section{INTRODUCTION}

The aim of this essay is to make in-depth inquires into a normative theory of judicial decision-making. Theories of judicial decision-making, in other words, theories of adjudication, fall into two categories. We can make a distinction between descriptive and normative theories (Leiter 2010: 1). Descriptive theories address the question of what judges do when they decide cases. The main issue here is what the real reasons, motives, psychological and social phenomena are behind the reasoning involved in judicial decisions. Sociological or psychological theories are interested in such kind of questions. We can mention here the Legal Realist movement's or Jerome Frank's ideas about judicial decisionmaking as attempts to highlight and describe the real facts behind judicial decisions.

Normative theories of adjudication try to answer the question of what judges should do when they decide cases, and focus on the question of how judges should justify their legal decisions. They attempt to reveal and analyse the principles and reasons that can serve as proper grounds for legal decisions. This theoretical analysis concentrates on the nature and the limits of judicial formalism.

Judicial formalism, on the one hand, is a judicial decision-making model for handling cases in a special way. As we shall see later, the term "adjudicative formalism" is used to mean that judges - when deciding particular legal cases - choose to apply the so-called source-based law and refuse to rely on reasons external to source based law (for example, moral principles, principles of equity or justice, the purposes behind legal rules and so on) (Schauer 1988-1989; Schauer 2009).

Krisztina Ficsor, Assistant Lecturer, University of Debrecen Faculty of Law. E-mail: ficsor.krisztina@, law.unideb.hu

(Received: 30.12.2013; revision received: 03.02.2014; accepted: 07.02.2014) 
On the other hand, in this author's opinion, formalism is a normative theory of adjudication which aims at justifying this decision-making model by exploring the principles which support formalist adjudication. That is, formalism gives distinctive answers to the question of what judges should do when they decide cases (Moore 1980-1981: 154). ${ }^{1}$ Thus, my purpose is to analyse the theoretical aspects and limits of judicial formalism.

So, the concept of "formalism" or "legal formalism" will be discussed in this text as it appears in adjudication and the term will refer to the so-called "judicial formalism". As the term "legal formalism" can be understood in many ways (Weinrib 1987-1988; Leiter 1999; Posner 1986-1987: 181), ${ }^{2}$ it must be emphasized that I will refer to this concept as a judicial strategy of reasoning and a normative theory of adjudication.

The reason for choosing this subject is that some Hungarian theoretical articles which are interested in analysing the practice of Hungarian courts (Bencze 2011; Bencze-MatzakKühn 2010: 81-89) have come to the conclusion that courts in Hungary are mostly engaged in formalist adjudicative methods. However, in Hungary, formalism is not considered a valuable and useful strategy in adjudication.

It is said that - among others - the main reason for engaging in formalist reasoning is the fact that the increasing workload forces judges to apply time-saving and less burdensome strategies of applying law. Formalism is thought to be the best strategy for solving cases easily within a short time and this sometimes results in unacceptable legal outcomes (Bencze-Matzak-Kühn 2010: 82).

Notwithstanding, formalism is much more than simply a resort to time-saving judicial strategies. My point is that it seems that in Hungary formalist judicial decision-making strategies are working elements of judicial practice; however, their formalism is not based on judges' commitment to the normative principles behind formalism. Their commitment to formalism serves only practical aims (e.g. finishing trials in a short time) and due to this attitude, they do not feel forced to think over the real content and the wider context of legal rules. This formalism manifests itself in understanding the simple meaning of legal rules without thinking over the whole context of legal cases.

However, formalism involves more than making "half-baked" or "unreasoned" decisions. Formalism in this fashion can be understood as a judicial strategy to cover the real reasons or motivations behind the decisions. As Frederick Schauer asserts, formalism can be understood as the "denial of political, moral, social and economic choices involved in the decision" (Schauer 1988-1989: 511). Notwithstanding this, my point is that formalist judicial strategies are able to manifest a real commitment to the normative principles behind formalism (e.g. the principle of the rule of law, the principle of democracy, the authority of

1 "Formalism is essentially a theory of adjudication. A perennial question of American jurisprudence has focused on what a judge does and should do in deciding a case. Any answer to this question may be called a theory of adjudication." (Moore 1980-1981: 154).

2 See, for example, the following "definitions" of formalism: "Formalism postulates that law is intelligible as an internally coherent phenomenon" (Weinrib 1987-1988). "Whereas positivism is a theory of law, formalism is a theory of adjudication, a theory about how judges actually do decide cases and/or a theory about how they ought to decide them." (Leiter 1999: 1144). "I want it (formalism $-K . F$.) to mean the use of deductive logic to derive the outcome of a case from premises accepted as authoritative. Formalism enables a commentator to pronounce the outcome of the case as being correct or incorrect, in approximately the same way that the solution to a mathematical problem can be pronounced correct or incorrect" (Posner 1986-1987: 181). 
law, the separation of powers, etc.). That is why a formalist decision can be the result of a careful consideration of the reasons behind the decision.

Thus, it is important to make clear what adjudicative formalism is, because this has been one of the most frequently criticized viewpoints in legal theory. The term "formalism" has usually been used in a pejorative sense. For example, we can think about the Legal Realist tradition in which formalism featured as the most unwelcome method of legal reasoning. However, formalism can be a valuable and a necessary part of legal reasoning, but it has its limits. So, an in-depth examination of the character of legal formalism enables us to judge whether it is an acceptable strategy in adjudication, and whether it is an adequate theory of judicial reasoning.

Because formalism is not merely about a blindfold adherence to rigid and thoughtless mechanical interpretative strategies, this essay will try to reveal and set out the most important theoretical approaches that are needed to be explained if we want to understand formalism. A normative theory of adjudication, when it makes clear its main considerations about the correct method of reasoning and interpretation, should not ignore the special character of law and legal reasoning. Thus, on the one hand, the theory of formalism should involve in its analysis that law claims legitimate authority. On the other hand, it should pay attention to the special character of legal institutions that are responsible for justifying their decisions and interpreting law. So, formalism as a normative theory of adjudication should take into consideration the function of adjudication and the special personal virtues and features of judges. Thus, the second part of the essay will try to find the connection between legal formalism and the theory of law, law's claim to authority, the theories about the function of adjudication and virtue jurisprudence.

\section{THE CHARACTER OF LEGAL (JUDICIAL) FORMALISM}

Let me start my analysis with the considerations of a formalist legal theorist, Robert S. Summers. According to Summers, formality is the fundamental character of law. By the "formal feature" of law he means that it is in various ways independent from the substantive content of law. Every basic legal phenomenon is formal in some important way. (The formal character of law manifests itself in fixed legal rules, legislative procedures, judicial interpretation and so on.) If we do not understand the important role of "form" in law we will not understand an important element of the nature of law (Summers 1992a).

These considerations throw light on an important feature of law, namely its formality. It is indeed the case that law usually manifests itself in formal and fixed rules, lawyers solve legal cases and apply norms within the framework of formal procedures. Formal rules regulate the ways and methods used to create law, citizens rely on fixed legal rules as reasons for their actions, and so on. It seems, that in modern democratic legal systems, fixed legal rules play a very important role in solving legal problems (Schauer 1991: 651-657; Bódig 2004). ${ }^{3}$

${ }^{3}$ However, I would not argue that the thesis regarding the formal character of law must be a conceptual claim about the nature of law. Rather, it is an empirical claim: it means that law in most modern societies manifests itself in formal phenomena, e.g. fixed legal rules, but it does not mean that this could not be otherwise. As Frederick Schauer asserts, it is possible to qualify a system - which does not contain, or whose decision-makers do not rely on fixed rules - as a legal system (Schauer 1991: 651-657). Thus, in this essay, I will take formality, and formal legal rules as an important feature of modern legal systems, but in the background of this claim I will accept the thesis that legal rules are not conceptual elements of law. The relation between rules and the law is contingent (Bódig 2004). 
Our task here will be to make clear the issue of what role the formal elements of law should play in judicial reasoning. The reason for analysing this question is that formalists usually insist on the claim that fixed legal materials must determine legal decisions. This is a normative claim, and our aim is to examine the adequacy of this thesis. To what extent should fixed legal norms determine legal decisions? Are there any situations when legal norms cannot serve as the basis of legal decisions?

As it was mentioned above, a specific kind of formalism is in the centre of this analysis, which we can call judicial formalism. In contemporary legal theory Frederick Schauer and Larry Alexander are the most prominent defenders of legal formalism of the sort that I will concentrate on. In their view, formalism is related to so-called rule-based decision-making and reasoning. Following Frank Michelman we can refer to this particular type of formalism as "rule-formalism" (Michelman 1999).

\section{II/a) Features of rule-formalism}

The central claim of this idea is that in law, lawyers must justify their conclusions with reasons stemming from the limited domain of law (source-based law) and judges are forced to restrict the scope of considerations that can figure in the decision-making process to the relevant legal reasons (e.g. to fixed legal rules). "By examining the possibility that law is a limited domain, I consider the proposition that there are in most advanced legal systems a substantial quantity of otherwise valid social norms, or otherwise valid sources of decision, that law refuses to accept. If law is a limited decisional domain, arguments permissible in other and larger domains become impermissible in law." (Schauer 2004: 1914-1915.)

It seems that the result of this thesis in adjudication can be that judges should refuse to base their decisions on moral, political or other extra-legal considerations, even if their conclusions based on the source-based law may seem to be - all things considered - unjust, or immoral (Schauer 2004: 1915, 1953). ${ }^{4}$ Formalists (Larry Alexander or Frederick Schauer), in other words, would say that formalism is about adherence to the legal norm's prescription "without regard to the background reasons the norm is meant to serve" (Alexander 1999: 531)..$^{5}$

The main feature of this conception is that taking into consideration the fact that sometimes it occurs that insisting on the application of source-based law (e.g. fixed legal

${ }^{4}$ It must be emphasized that I take the limited domain thesis as a normative thesis about law. In Schauer's conception it is rather an empirical thesis. "The limited domain claim is both empirical and a matter of degree. Law may be more or less a limited domain, and the interest lies in the 'more' or the 'less."' (Schauer 2004: 1915.) However, I think that the limited domain thesis imposes a normative burden on adjudication. If the law is a limited domain of reasons, then judges' decisions must be based on those reasons that stem from this limited area. Schauer also throws light on the normative aspect of the limited domain thesis. Even the concept held by those legal positivist authors, who established a conceptual theory of law (e.g. Bentham) also involves a normative commitment. They did not just believe that law should be conceptually isolated from other normative fields of discourse, but they insisted on the requirement that judges' decisions must rely on reasons from this limited domain (Schauer 2004: 1953).

5 However, a very important problem is raised by the issue of "source-based law" and "rulebased decision-making". It is not obvious that source-based law is identical to fixed legal rules. However, it seems that the kind of formalism that I focus on takes legal rules as the relevant elements of source-based law. In my opinion this is the reason the problem of formalism includes the question of what law is. But this question will not be analysed in this essay in detail. 
rules) does not serve the background reasons and purposes of the rule in a particular case. "Rules may point to results that diverge from those that a decision-maker would have reached apart from the literal meaning of the rule." (Schauer 1987-1988: 530.) If this is the case, a formalist judge is unresponsive to the substantive ends of the rule and indifferent to other reasons than the text of the rule (such as moral reasons). Formalism is about the idea that law is a distinctive area of practical deliberation which excludes some considerations which "would otherwise be relevant to the situation" (Bódig 2008: 9). ${ }^{6}$

\section{II/b) Formalism and the problem of interpretation}

A further question needs clarification. Applying fixed legal norms cannot be realized without interpretation of these norms. Interpretation of legal materials is the most important element of adjudication. Legal reasoning is interpretive in the sense that legal practitioners extract the reasons, which can function as the legitimate basis of their decisions, from legal materials by interpreting those materials (Bódig 2006: 35). Thus, an essential part of our analysis is to answer the question of what formalists think about the issues of interpretation: how is it possible for a judge to insist on applying the fixed legal materials?

It seems, formalists have not developed a common conception of the issues of interpretation. Some of them (for example Frederick Schauer) support the thesis of semantic autonomy. This means that what makes it possible for a judge to apply legal rules without relying on extra-legal considerations, is the fact that words and sentences are able to have acontextual meaning. The fact that we have "linguistic competence" in speaking a language provides us with the opportunity of understanding words and sentences without knowing the wider contexts of these words or sentences or the background intentions and aims behind them (Schauer 1987-1988: 526-528). It seems the result of this consideration is that revealing the plain meaning of rules can play a central role in supporting legal decisions. Or in other words, the nature of language ensures the opportunity for the judge to apply legal rules without relying on the background reasons, justifications and wider context of the rule.

However, according to Schauer, it must be clear that this is not a normative claim. This is rather an empirical claim: it is possible for judges to refuse to rely on considerations other than fixed legal rules because the language of rules (the plain meaning of rules) can often be certain enough to determine legal decisions. However, judges are able (e.g. in a psychological sense) to ignore the relatively clear meaning of rules and it is possible that they base their conclusions on extra-legal reasons, for example, on reasons stemming from equity, or justice and so on. There is a choice for judges in adjudication, and it is true that either the choice of relying on the plain meaning of rules or ignoring the application of rules can be found in the judicial practices of modern legal systems. We cannot say which judicial "strategy" prevails over the other (Schauer 2009: 29).

In Hungary László Blutman defends textual interpretation by deploying many arguments supporting this kind of interpretative strategy. By textual interpretation he means the judges' efforts to figure out the plain or ordinary meaning of words and sentences (Blutman 2010: 95). Finding out the plain meaning of legal concepts is important because this is the only interpretative strategy that makes possible intelligible and predictable communication and reasoning about legal issues among legal professionals. Plain meaning

${ }^{6}$ Bódig, M.: Rules, Principles, and the Problem of the Limits of Legal Reasoning. Electronic copy available at: http://ssrn.com/abstract=1318638. p. 9. 
is the relatively objective ground of legal reasoning which makes legal decisions more predictable. Ignoring the clear meaning of legal texts - engaging in moral reasoning for example - entails the possibility of relying on subjective preferences or establishing an incoherent and inconsistent legal practice (Blutman 2010: 97-99).

In fact, defending the value of predictability, stability and certainty in law and in legal reasoning is consistent with formalism. Insisting on textual interpretation can be a good instrument for formalists to guarantee the requirement to isolate legal reasoning from political and moral reasoning, and by virtue of this, provide a predictable, stable practice of reasoning and decision-making. Plain or ordinary meaning can be taken by them as the objective ground of legal reasoning which cannot be related to moral or political issues. ${ }^{7}$

However, others would say that "interpretation in law and in life is a search for speaker's meaning." (Alexander-Sherwin 2008: 133). This means that judges, when they interpret a statute, should seek and reveal the intentions of the legislators; in other words, judges should figure out what the legislators wanted to communicate by creating the particular rule. The reason for this is that the "plain meaning" of words and sentences is always determined by the speakers' intentions. The grammatical meaning of words and sentences are only the "reports of the speaker's meaning" (Alexander-Sherwin 2008: 134). That is why meaning can never be isolated from the intentions of the speaker and the context of the text's creation. Meaning is always communicated by intentions (AlexanderSherwin 2008: 135). The result of this is that a judge, as a formalist decision-maker, only decides according to fixed legal norms (source-based law) if she understands legislative intentions (Solum 2010: 95-108; 95-98). ${ }^{8}$

\section{II/c) The central arguments of my analysis}

Without committing myself either to the first or the second interpretation I state my case here in advance.

1. At the centre of my theoretical attention will be those cases in which the meaning of legal rules are relatively clear and judges are able to give relatively clear answers to the question before them by simply relying on the plain meaning of the rule. These cases can be called "easy cases".

2. However, I think it can happen that these kinds of clear cases become hard when the decision derived from the plain meaning of the rule is irrational, unjust, or inconsistent with the principles of equity or political morality. Formalism means - as I stated above - that in such cases judges should ignore reasons other than the clear meaning of the rule.

${ }^{7}$ However, it is a matter of an analysis of the nature of language whether this thesis is correct.

8 Regarding the questions of interpretation, it can be a very useful analysis from the point of view of formalism, if we take into consideration the distinction between interpretation and construction. See Solum 2010: 95-108. The distinction refers to the difference between interpreting a text and the activity of construction. According to L. B. Solum, applying a legal text to a particular case involves two stages. The first is interpretation, which is aimed at discovering or recognizing the linguistic meaning of the text and nothing more. Construction is the second element of applying a legal text, which gives legal effect or legal content to the text by translating it into a legal doctrine (Solum 2010: 95-98). The latter is not part of the "simple" or "plain" linguistic or semantic content of the text. The interesting question for formalism is whether it is justified to "overrule" the clear text of the legal rule by construction or when it is justified to engage in "constructive" application of law by ignoring the clear meaning of the statute. 
3. This kind of formalism is a valuable judicial "attitude", and plays a central role in law. There are cases when judges engage in an "intelligent" or justifiable formalism. In this case, the formalist decision is the result of a careful consideration of the reasons for making a formalist decision in the particular case. However, I will argue for the claim that there is an unintelligent or unjustifiable kind of formalism, too. The latter means that the judge insists on revealing the plain meaning of the rule while the correct solution of the case demands that other kind of reasons (for example moral principles, the requirements of equity, justice) should be balanced. The reason for the impropriety of this formalism is that the particular case cannot be solved in the right way by resorting only to the text of the most applicable legal rule. There are cases when formalist judicial behaviour, that is, having resort to the rule cannot be an adequate basis for reaching the right legal answer.

4. My point is that the problem of formalism - that is, the issue of when formalism is justifiable and when it is not - is a theoretical issue. I mean by this that this question cannot and should not be answered in a case by case analysis: the judge should not decide this question according to the circumstances of the cases before him. This entails that the borderline between easy cases and hard cases is not clear. Even if it is clear and certain what a legal rule requires in a concrete case, it is not enough to treat it as an easy case. There is almost always the possibility that an easy case will become a hard case if the relatively clear meaning of the rule does not lead to a just, fair or - taking every relevant feature of the case into consideration - right decision. Formalism concerns the question of what judges have to do when faced with this kind of decisional situation.

5. Thus, the main question of this essay is whether there is a theory of legal reasoning which is able to account for the necessity of formalism in legal reasoning and at the same time is able to explain that there are cases where formalism is not the right strategy. What are the limits of formalism? Are we able to answer this question within the framework of an adequate theory of legal reasoning? Further theoretical analysis will show that this is not possible. The analysis should go beyond a theory of legal reasoning.

First, let me consider two examples from Hungarian judicial practice. One of them will be an example of justifiable formalism and the other will be an instantiation of an unjustifiable formalism.

\section{JUDICIAL DECISIONS FROM HUNGARIAN LEGAL PRACTICE}

\section{III/a) Decision of the Court of Budapest: Nr. 4. P.III.25.549/2006/47}

A testator in his last will left his possessions to an association established by the testator some years before. The testament consisted of two pages and only on the second page was a page number. The legal heirs sued the association and they claimed that the testament was not valid because it did not meet the requirements of the rules of law. According to section 629 (2) of the Hungarian Civil Code a will that contains more than one page is valid only if each and every page is numbered. [629 (2) A holographic will consisting of several separate pages shall be deemed valid only if each page is numbered in sequence and signed by the testator and, if witnesses are needed for the validity of the will, also signed by both witnesses.]

The respondent's main argument was that formalism is not the right strategy in deciding testamentary cases; instead of this, courts must decide in favour of the testator's will. This particular testament absolutely reflected the testator's will, moreover - except for 
the page numbers - all the other elements met the requirements of the rules of the Civil Code. Thus, the court should not prefer the plain meaning of the rule to the testator's will.

The court concluded that the clear meaning of legal rules cannot be ignored by referring to the incorrectness of formalism. The Civil Code clearly determines the formal requisites of a valid testament; thus, the court should not turn from the plain meaning of the rule. Even if there is only one formal defect which - all things considered - seems insignificant, the testament is invalid.

This decision can be conceived of as a carefully considered commitment to formalism: it took the formal requisites determined by the rule as a guarantee whose purpose is to prevent others from changing the pages and the content of the testament arbitrarily.

However, not every judicial decision is an example of an intelligent formalism. Many decisions reflect the unwelcome type of formalist attitude.

\section{III/b) Decision of the Court of Budapest: Nr. 41. Pt. 640 715/2070/3}

In the following case the plaintiff was a journalist who sued a consortium called MH-2009 Consortium. The factual basis of the case was connected to the renovation works on Margit Bridge in Budapest and to the fact that the data concerning the financial implementation of these renovation works were unavailable to the public. The plaintiff referred to his right to know the financial management data for the renovation works as these data were, in his opinion, public information subject to disclosure. The Consortium and the local government of the capital city refused to provide the financial statement arguing that this information constituted a trade secret. So the plaintiff asked the court to require the respondent to publish the Consortium's financial statement.

The arguments of the plaintiff were the following: Margit Bridge is in the possession of Budapest City Council, the capital city is responsible for renovating the bridge which is a public responsibility. In consequence, all data which can be connected to the maintainance works are public information and every citizen has the right to know them. Since the local authority does not have the adequate professional skills and technical facilities to implement the renovation project, it entered into a contract with the Consortium and they agreed on the conditions of the renovation work. According to this contract, the Consortium worked on the renovation of the bridge and all the costs were covered by the state and the local government of Budapest. It follows - the plaintiff claimed - that even if the Consortium is a private firm, it has public responsibilities, it manages public properties and spends public money; therefore, the data concerning this project are of public interest and they must be published.

The Civil Code of Hungary only stipulates that public duties are carried out by state institutions or local authorities. However, the plaintiff claimed that the concept of public duty is broader than what is determined by the legal rules. There must be a principle or a background meaning behind the rules which stipulates that the essential element of this concept is that if the duty serves public interests and public aims and is financed by public resources, then the financial data connected to its performance are open to disclosure.

The conclusion of the court was the following. The court emphasized that access to data of public interest is a constitutional right of every citizen. However, there are conditions attached to accessing the data: the data must be of public interest and they must be handled or processed by a state institution or a local government.

The relevant legal rule which had to be applied by the court was section 19 (1) of Act of LXIII of 1992 on the Protection of Personal Data and the Disclosure of Information of 
Public Interest. According to this section the state or local public authorities and agencies and other bodies attending to public duties specified by law shall provide the general public with accurate information and in good time concerning the matters under their competence, such as central government and local government budgets and the implementation thereof, the management of assets controlled by the central government and by local authorities, the appropriation of public funds, and special and exclusive rights conferred upon market actors, private organizations or individuals.

However, the court concluded that the respondent, i.e. the Consortium, is not a state institution and neither the state nor the local authority of Budapest has a market share in this firm. It is a private firm. The fact that a local government enters into a contract with a private firm does not entail that the private firm takes over the performance of the public duty from the local government. The private firm's services cannot be related to the performance of a public duty, only to the extent that the costs were covered by the state and the local authority's budget. The court referred to other sections of this statute, but it insisted on the plain meaning of these sections and stipulated that the services provided by the Consortium were not mandated by law or any contract; it was not a state or a local governmental institution.

The conclusion is that the Consortium has no obligation to provide the public with information on the financial management of the renovation works. The Highest Court of Hungary (Kúria) confirmed every element of the argumentation of this decision.

The implications of the court's formalism are unacceptable. The court adhered to the text of the rules and refused to analyse the policies behind them. The principle mentioned by the plaintiff was later incorporated into The Fundamental Law of Hungary: Article 39 (2) Every organisation managing public funds shall be obliged to account for its management of public funds to the general public. Public funds and national assets shall be managed according to the principles of transparency and the elimination of corruption. Data relating to public funds and national assets shall be data of public interest.

If this principle had been taken seriously the court could have departed from the strict meaning of the rules, and could have had the opportunity to oblige a private firm to provide the financial statements, since the relevant conceptual element of public duty is not the type of the performing institution involved but the fact that it manages public funds.

\section{THE THEORETICAL LIMITS OF LEGAL FORMALISM}

It should be emphasized that formalism is a valuable judicial attitude; however, it is not valuable for its own sake. As I stated above, formalism has its limits. There are cases when it is not enough to rely on the relatively clear meaning of fixed legal rules. That is why, in my opinion, it is worth searching for a theoretical basis by virtue of which we are able to decide when the formalist attitude of judges is justifiable and when it is not. The main question here is what the theoretical difference is between two cases when one of them is an example of justifiable formalism and the other is not. There are some theoretical approaches to adjudication that offer some answers to this question. My aim here is to make clear that the limits of formalism cannot be fixed on the basis of a case by case analysis. What I mean here is that the limits of formalism are a matter of theory and it is not determined by the particular features of legal cases. Let me give a short analysis of those theoretical considerations within which the problem of formalism can be handled. 


\section{IV/a) Presumptive formalism}

The first theoretical approach which is able to provide the answer to our question is the theory of Frederick Schauer. An important feature of his idea is that it is not the case that formalism is always good, or that judges should always be formalists. His idea is called "presumptive formalism" which means that there should in every case be a presumption in favour of the outcome based on the "most locally applicable rule", which is the rule or a statute "which most narrowly pertains to the situation at hand" (Schauer 1987-1988: 517). However, if there are compelling reasons against the text of the legal rule, then judges can turn from the literal meaning of the law. However, formalism has priority over non-formalist attitudes.

The normative principle which is used to justify this kind of decision-making method is the principle of the separation of powers. In short, it is about the idea that judges are not authorized to depart from the written text of the legal rules - it is for the legislator to decide moral or political questions. According to this idea, formalism is about power (Schauer 1987-1988: 543). This means that a formalist decision-maker is committed to the view that, no matter how compelling the circumstances which urge him to depart from the text of the rule, he is not empowered to decide against what the law says. As Schauer says: "Part of what formalism is about is its inculcation of the view that sometimes it is appropriate for decision makers to recognize their lack of jurisdiction and to defer even when they are convinced that their own judgement is best." (Schauer 1987-1988: 509.) According to this view, formalism is a valuable adjudicative model in those political systems where it is desirable to narrow down the decisional possibilities of certain democratic institutions.

However, according to Schauer, the judgement about when to engage in formalistic reasoning is a contextual, psychological or political matter rather than a logical or a conceptual question (Schauer 1987-1988: 544). Notwithstanding this, I would like to argue for the claim that the problem of formalism should not depend on contextual questions, or on the psychological attitudes of the judges - it is a normative question. The normative question of formalism should not be dependent on case by case decisions. Despite this, it seems that Schauer differentiates between two types of cases; in one type formalism is an acceptable judicial strategy, while in the other it is employed to make a rather non-formalist decision. Taking his examples into consideration, two kinds of hard cases can be distiguished. One kind covers those cases in which, although the semantic or linguistic content of the rule is relatively clear, the decision derived from this clear meaning would come into conflict with the principles of equity if the judge were to pay attention to the relevant particular circumstances of the case. It is possible to take Schauer's "eviction of starving people" example as a case falling under this category of hard cases. The eviction of starving people by insisting on the clear meaning of the rule is not acceptable. This kind of formalism is condemnable (Schauer 1987-1988: 543). Other examples can be mentioned from legal history, like the famous decisions made by Magnaud on the basis of equity, which are obviously instances of this kind of hard cases.

The essential character of these hard cases is that the special circumstances of the plaintiff or the defendant, or the peculiar features of the factual situation require the judge to take the principles of equity into consideration and to diverge from the clear meaning of the rule.

However, the other type of hard cases is the one in which without balancing the principles of political morality, the case cannot be decided in a correct way. In these kind of cases, the judge is not "forced" to rely on equity; rather he faces the possibility of 
interpreting a concept of political morality. For example, solving the case requires that judges interpret the concept of liberty, human dignity, responsibility, autonomy or some less abstract principles behind the fixed legal rule. Among Schauer's examples are cases whose solution is connected to the Amendments of the Constitution of the United States. But it is possible to refer to Hungarian cases, too, in which trial courts had to balance principles of political morality or constitutional rights and it was not just the text of the most applicable rule which was taken into consideration (Bencze 2011: 77-109). However, Schauer argues for the claim that in this kind of case the judge is required to make modest decisions and to refuse to balance all relevant reasons and factors in the case. These cases require judges to be formalists (Schauer 1987-1988: 543).

It seems that the relevant normative principle which can be a guiding line for deciding whether a formalist strategy is justified or not, is the separation of powers. According to this constitutional principle decisional powers are allocated to different institutions in a democratic political community. Judges are not allowed to decide all kinds of questions. Their main task is to respect the main elements of source-based law - especially legal rules and statutes - and only compelling reasons can justify the "overruling" of the text of the most locally applicable rules. In cases where the conflict between the decisions derived from the legal rule and the principles of equity or justice or other non-legal reasons is not too obvious or not too strong, there is no justification for ignoring the rule's clear content. Judges have to respect the legal rules' presumptive force and they are only allowed to turn from them when the non-legal reasons are compelling and outweigh the reasons for following the rule (Schauer 1991: 676).

Schauer's answers to the problem of formalism are very convincing. His theory of legal reasoning is able to take into account the idea that while formalism has to be an important part of judicial reasoning, it does, however, have its limits. Presumptive formalism is able to explain that the elements of source-based law have an authoritative or pre-emptive force. Rules are not just good advice for citizens and judges on how to act. Moreover, it takes into consideration the idea that extreme formalism is not a valuable or acceptable strategy of reasoning, so judges should realize when source-based law should be outweighed by relevant non-legal reasons. However, we still can see the problem of when and how judges can decide whether it is justified to ignore the clear meaning of legal rules and when it is necessary to make a formalist decision even if it is in conflict with the relevant nonlegal reasons. What is the theoretical line between justified and unjustified formalism? Is it possible to draw any theoretical lines between these two categories in judicial practice or is it really a matter of case by case considerations? What are the theoretical limits of formalism?

If we mention the principle of the separation of powers as an answer to the problem of formalism, it becomes clear that this issue cannot be answered only within a theory of legal reasoning. The separation of powers is a principle of institutional design in a democratic political community. Thus, it seems, the theory of legal formalism and the issue of the limits of formalism calls for the solution of other questions that are beyond the issue of the theory of legal reasoning and interpretation. In my opinion, there are more questions that must be discussed to understand the problem of formalism.

The first is the theory of law, and the question of what law is. If we accept that the law is a distinctive area of normative discourse, and if judges are bound to apply and rely on reasons stemming from this distinctive discourse, then we should say something about the boundaries of this normative phenomenon called law. In short, we have to answer the question of what law is. 
The second question is the authority of law. Within this analysis we have to make clear what kind of obligatory force law has. In short, it must be explicated what kinds of practical reasons are provided by law to judges. That is, the question is where the obligation of judges to decide according to law stems from. Does source-based law have absolute peremptory force or can it be outweighed by other relevant non-legal reasons? What does pre-emptive and conclusive force mean in law?

The third question to be analysed is the function of judges. Here the task is to explain what the function of judging is in a political community which is committed to democratic or constitutional principles such as the separation of powers. This question can be connected to the issue of "institutional design" (Bódig 2008) ${ }^{9}$ or constitutional structure (Manning 1999). What kind of decisional power do judges have in a democratic political community? What type of issues are they allowed to decide and what are those cases that they should refuse to decide? What are the real tasks and functions of a judicial institution?

The answer to all these questions determines the answer to the problem of legal formalism. If our aim is to take a stand on the acceptability of formalist legal reasoning and interpretation, then we have to take into consideration the above-mentioned issues that are prior to the theory of legal reasoning and legal interpretation.

In the following sections I give a short summary of these considerations.

\section{IV/b) The theory of the nature of law and the theory of adjudication}

Given the requirement that the judges are obliged to justify their decisions by relying on reasons stemming from a distinctive area of practical reasoning, called law, the problems of formalism can, be connected to the wider questions of what law is and of what reasons can be taken as parts of the law. This debate concerns the relationship between the theory of the nature of law and the theory of legal reasoning or adjudication. This is the debate which arose between Joseph Raz and Ronald Dworkin.

Raz, as a legal positivist, stands for the claim that the task of legal theory is to define what law is. Moreover, the definition of law must be given without resorting to moral, political or other considerations so that law can be identified as a special area of reasoning which differs from other normative systems such as morality. The task of legal theory is to reveal the law's distinctive features ( $\operatorname{Raz} 2009: 17)$. On the contrary, theories of adjudication have a different function: they have to explore the character of legal reasoning. They give an account of the question of how and why judges rely on extra-legal considerations. The aim of the theories of adjudication is to explain that legal reasoning often includes arguments that are not parts of the law.

However, Ronald Dworkin asserts the opposite of this claim. According to him, the principles of political morality are part of the law and judges must rely on them when they decide cases. This statement means that every legal proposition is valid only if it fits into the coherent system of the principles of political morality which justifies the existence and the authority of law (Dworkin 2011). It seems that from a Dworkinian point of view, a formalist judicial decision is justified only if it has a place in this coherent system of principles. "[...] law includes not only the specific rules enacted in accordance with the community's accepted practices but also the principles that provide the best moral justification for those enacted rules. The law then also includes the rules that follow from

9 Bódig, M.: Rules, Principles, and the Problem of the Limits of Legal Reasoning. Electronic copy available at: http://ssrn.com/abstract $=1318638$ 
those justifying principles, even though those further rules were never enacted" (Dworkin 2011).

The most important concept that explains this statement is the idea of integrity. The value of integrity requires judges to identify legal rights and duties as if they all were created by a single author who expresses "a coherent conception of justice and fairness". Propositions of law are true if they incorporate the basic principles of political morality. Integrity (the value of coherence) urges judges to assume that law is organized according to a coherent set of principles and asks judges to enforce them in new cases (Dworkin 1986).

This theory can be a relevant candidate for explaining why some formalist decisions are jusitifiable and why certain formalist conclusions are not. However, according to some critics this theory has to face the problem that it cannot "account for the dual need for efficient authoritative guidance and the openness of law to critical challenges" (Bódig 2008: 15).$^{10}$ It seems that we have to face some criticism concerning Dworkin's theory. The main point of these criticism is that there is no place for the view that legal rules (source-based law) creates obligations to act and decide according to their prescriptions. In the Dworkinian theory there is always an opportunity to ignore legal rules in the light of a principle. According to the critic, this theory cannot account for justifiable formalism in legal reasoning.

As we stated above, we are committed to the view that formalism - deciding according to the prescriptions of legal rules even if the decision does not meet the requirements of the relevant non-legal reasons - must be a part of judicial reasoning. That is why we have to take the implications of these criticisms seriously and create a theory about the nature of law and its relationship with theories of adjudication.

\section{IV/c) The authoritative force of source-based law}

A further issue that can emerge in the explanation of the problem of formalism is the preemptive force of source-based law, i.e. the authority of law according to the Razian conception. The starting point can be the following statement about the nature of law: law forms a claim to legitimate authority, which means that authority has a right to provide reasons for action in a given decisional situation. "[...] authority is a right to rule, the theoretical question is how to understand the standing of an authoritative directive [...]. If issued by someone who has a right to rule, then its recipients are bound to obey. The directive is binding on them and they are duty-bound to obey it." (Raz 2009: 134.)

In the Razian view the reasons for actions provided by law are authoritative reasons, which means that the way they influence practical reasoning is special. Reasons are the basis for justifying human decisions and behaviours; they guide actions and are also relevant in evaluating actions. When an authoritative reason guides behaviour it means that it changes the circumstances of justifying actions and decisions. In everyday life we act and make decisions by thinking over and pondering the reasons for and against a concrete action. In normal circumstances we make a decision or perform an action that is supported by the strongest background reasons. However, when an authoritative reason, e.g. the action involves a legal rule, then the circumstances in which we ponder the reasons for actions change. "Of course, authority is special in the way in which it restricts one's ability to act independently. [...] authoritative directives pre-empt those reasons against the conduct they

10 Bódig, M.: Rules, Principles, and the Problem of the Limits of Legal Reasoning. Electronic copy available at: http://ssrn.com/abstract=1318638. p. 15. 
require that the authority was meant to take into account in deciding to issue its directives." (Raz 2009: 140.)

Law, as an authoritative reason, pre-empts those reasons that could be relevant in supporting the action or decision, even if the decision according to these other reasons would be wiser or more rational than the decision according to law. Law - when it applies to the case - forms a claim to be the sole reason for action and pre-empts the possibility of pondering other non-legal reasons for and against the action. "Those subject to the authority are not allowed to second-guess the wisdom or advisability of the authority's directives." (Raz 2009: 141.)

Another important feature of law as an authoritative reason is that it creates exclusionary reasons for action: they are reasons for not following those reasons that result in a different decision or action from the one required by law. The pre-emptive force of law shows itself as an exclusionary reason. It excludes those reasons from the process of balancing of reasons for action that conflict with the prescription of the law. Even if authority makes mistakes, we have an obligation to comply with its prescriptions (Raz 2009: 144-145.) These considerations can be expressed by the words of Robert Summers, when he says that the reasoning under a system called law is formal, which means the following: "First of all it is authoritatively formal. It derives from or it is generated by legally recognised phenomena - in this case a legal rule. Second, it is mandatorily formal [...]. That is, it generally overrides any competing substantive reasoning that may emerge at the point of application." (Summers 1992b.)

From the formalist point of view the following question is relevant among these considerations: what sort of obligation is imposed on judges by law as an authoritative normative phenomenon? Does this mean that judges are not allowed to consider other factors than the reasons stemming from the source-based law?

The answer can be found in Joseph Raz's considerations: "Authoritative directives are not always conclusive reasons for the conduct they require. They can be defeated by conflicting reasons, or by conflicting directives. The reasons that can defeat them are those they do not exclude." (Raz 2009: 145.)

The theoretical issue that should be answered here is the scope of non-legal reasons that must be excluded from legal reasoning and the scope of non-legal reasons that can be taken into consideration by judges when they decide cases. What sort of reasons should be excluded and what sort of considerations are allowed to defeat authoritative legal reasons?

Joseph Raz gives an answer to this question. According to him, not all conflicting reasons are excluded, just those that have already been considered and pondered by the lawmaker before it enacted the legal rule. However, is it possible for a judge to figure out what kind of reasons were taken into considerations by the lawmaker in the parliamentary discussion of the rule? Moreover, is it possible to offer a theoretical answer to the question of what sort of reasons should be excluded from judicial reasoning when she has to decide in a concrete case? Or is this issue only a matter of case by case analysis?

The theoretical question here is that we have to reconcile the fact that the law claims legitimate authority and as a result of this, claims pre-emptive and exclusionary force, and the fact that in judicial practice it often occurs that judges rely on extra-legal reasons and arguments. What are the consequences of this on the pre-emptive and exclusionary force of law? What can be the reasons for judges to rely on extra-legal considerations and how is it possible to justify these decisions?

My point is that this question is closely connected with the problem of formalism. As it was stated above formalism is strongly connected to the view that judges should rely on 
reasons that stem from a restricted area of practical reasoning. If judges rely on considerations that are in conflict with the source-based law, or reasons that are not supported by any legal rules, then whether this can be justified or not should be answered theoretically. This is a central question for formalism, which should be made clear.

\section{IV/d) The function of adjudication}

However, it is not just the questions of "What is law?" and the pre-emptive force of law which can be related to the problem of formalism; another perspective should also be taken into account. The problem of formalism can be handled within a broader theoretical framework which concentrates on the function of adjudication within an institutional structure of a constitutional democracy. According to this idea, "we need theories that try to handle the problem of legal reasoning in connection with issues of institutional design" (Bódig 2008: 15). ${ }^{11}$ The problem of formalism can be solved by establishing an institutional structure that allows both rule-based decision-making and principle-based reasoning to exist together in law. "If one accepts that the Constitution ultimately defines the scope and limits of all governmental authority at the federal level, then the legitimacy of the judiciary's development and application of interpretive rules must be justified by reference to the Constitution. To pursue any particular interpretive goal [...] judges must be able to conclude either that the Constitution calls for (or at least inspires) the pursuit of those goals or that the federal courts themselves have inherent authority to adopt and apply such interpretive norms in the exercise of the judicial power." (Manning 1999: 690-691.)

Within this theoretical framework, our task is to explore the real institutional function of adjudication. We have to answer the question of what is expected from judges in a constitutional democracy that is committed to the values and principles of democracy, the rule of law and the separation of powers. Here we also can mention several theoretical approaches that must be examined if we would like to make this issue clear. First, it is possible to unfold a theory which concentrates on the "rule-applying" function of judges. The essence of this theory can be the claim that the function and real task of judges is to apply and interpret what is written in fixed legal rules (Dworkin 1985: 11).

However, there are different approaches. Ronald Dworkin's theory focuses not on the written rules, but on (moral) rights that citizens have in a political community. For him the task of the judge is to take rights seriously, because citizens do not only have those rights that are backed by fixed rules. Our rights stem from the political morality of the community, and we can enforce them in courts even if they are not provided by fixed legal rules. "The rights conception [...] supposes that citizens have moral rights - that is, rights other than and prior to those given by positive enactment - so that a society can sensibly be criticized on the ground that its enactments do not recognize the rights people have." (Dworkin 1985: 13.)

A third theoretical approach can be explicated as well, according to which the essential role and function of judges is to do justice. This theory commits itself to the claim that the judge should not only apply fixed legal rules, but should do justice when deciding cases. "The adjudication in each case must result not only from an application of a legal rule but, also, in what the judge feels to be a result that is as fair as possible to the individual interests concerned." (Tate, 1975: 250.)

11 See Bódig, M.: Rules, Principles, and the Problem of the Limits of Legal Reasoning. op. cit. 15. 


\section{IV/e) Virtue jurisprudence}

This thesis leads us to another theoretical approach to judging, which can be called virtue jurisprudence. According to this theory, the basis of judges' decisions is justice, where just decisions are made possible by having practical wisdom. Within this theory judicial virtues are the most important requirements needed to be a good judge and make the right legal decisions.

The most detailed explanation of the virtues of judges and a virtue centred theory of law is provided by Lawrence B. Solum. His theory implies the thesis that "judicial virtues are a necessary part of the best theory of judging" (Solum 2003: 184).

The central claim of Professor Solum is that a virtue-centred theory of judging proceeds in a different way from the so-called decision-centred theories. The starting point of decision-centred theories is the criteria of right legal decisions. Their main task is to seek and work out the normative principles which make a legal decision justifiable, right or good. Only after this is achieved will they try to find the judicial virtues that can contribute to making the right decision. Virtues are derived from the notion of the right decision. However, a virtue-centred theory follows another path because it claims that the first step of theoretical analysis should concentrate on judicial virtues and then the criteria of justifiable decisions can be derived from these virtues (Solum 2003: 184).

Judicial virtues are part of human excellence in general. These virtues fall in the categories of theoretical wisdom, practical wisdom or are moral virtues. All of them are needed for a judge to make justifiable decisions. These virtues are judicial temperance, courage, temperament, intelligence, wisdom and the virtue of justice. Among these, the latter, wisdom of justice is the most important and central to the theory of judging. "If we know anything about judges, it is that they ought to be just." or "[...] justice is an essential virtue for excellence in judging" (Solum 2003: 194).

The wisdom of justice includes three important attitudes of a judge. First, she should be impartial. A good judge understands and takes the interests of every person involved in the conflict into consideration and does not give priority to the interests of any of the participants. Second, a good judge has fidelity to law and can see the law as a coherent order. Fidelity to law manifests itself in judicial integrity, which means that the judge is unwilling to "improve" the law and reluctant to create uncertainty and inconsistency in law by ignoring the prescriptions of rules and legal standards. The third element of the virtue of justice is a sense of the situation at hand, a "legal vision, the ability to size up a case and discern which aspects are legally important. This requires an intellectual grasp of the content of the law, an understanding of the underlying purposes the law serves, and an ability to pick out the features of particular cases that are important for those rules and purposes." (Solum 2003: 197.) It is not possible that only one or two of these elements of the wisdom of justice contribute(s) to the right decision. All these parts must be present in the judge's personality as a "coherent" structure of virtues to make just and right legal decisions.

Virtue jurisprudence is relevant in the analysis of formalism because it has a relatively clear answer to the question of when formalist decisions are justifiable and when they are not.

The following part of Professor Solum's theory throws light on the problem of formalism. He distinguishes between two kinds of cases. One type of legal cases can be called "justice as lawfulness". In such cases the decision required by the legal rules is consistent with the judge's sense of fairness. Very often, the outcome required by the plain 
meaning (the letter) of laws is in accordance with justice. In every case, the judge must justify her decision and justice requires judges to explain their decisions on the basis of legal rules. This procedure requires the judge to have all the judicial virtues that were listed above: practical wisdom is needed to apply legal rules correctly (Solum 2003: 200-204).

The other type of cases is called "justice as fairness". In this kind of case the outcome required by the legal rule is not in accordance with the judge's sense of fairness. These cases give the opportunity for the judge to practice equity. Justice here requires judges to depart from the rule's prescription. Where the rule leads to an unjust decision, the task of the judge is to make exceptions from the rule or to correct the defects of law, that is, to take the particular circumstances of the case into consideration and depart from the rule in accordance with the requirements of equity. This cannot be achieved correctly by relying on the judge's own preferences. The practice of equity must be based on judicial virtues. Only a virtuous judge is able to decide whether it is justified to depart from the rule, or not. Only a judge with a virtuous personality is able to decide on the principles of equity (Solum 2003: 204-207).

"There are cases in which the just outcome can only be recognised by a virtuous judge." (Solum 2003: 199.) So, a virtue-centred theory concentrates on judicial virtues as the fundamental grounds of just and right decisions. Thus, a virtue-centred theory can be a "candidate" which provides a theoretical basis for the problem of formalism. A judge who has theoretical and practical wisdom, judicial courage and temperance, and is able to decide according to the requirements of the wisdom of justice, will always decide cases in the right way. A virtuous judge will always know when it is justified to depart from the clear meaning of the rule and when it is not.

However, one question remains to be answered. Judges are human beings, and not all of them have all the kinds of virtues that are required. Human beings are not perfect and even a virtuous judge can make wrong decisions. The question of formalism can be approached in a way that makes clear this imperfect character of human beings. Some formalists could say that we should pay attention to the fact that judges are human beings, have different capabilities and different virtues, and that is the reason why it should not be their task to decide whether departing from the clear meaning of the rule is justified or not. Insisting on the rule's prescription can contribute to fewer judicial failures and mistakes and imposes the responsibility for mistaken or unjust legal decisions on the legislator.

\section{SUMMARY}

My central case was that formalism is a theory of adjudication, it concerns the question of how judges should decide legal cases. However, my point is that the problem of formalism cannot be solved only within the framework of a theory of adjudication or legal reasoning because it can be connected to other issues that have to be analysed if our aim is to understand the nature and limits of formalism. The problem of formalism raises the theoretical issues of the nature of law, the authoritative force of law, the functions of adjudication in a modern democratic political community and the institutional structure of modern constitutional democracies. Moreover, it seems, the theoretical considerations of virtue jurisprudence cannot be ignored either.

The problem of formalism is about reconciliation. The reconciliation of the most important values that have to be realized by modern legal systems. For example the values of stability, certainty and predictability, which are important requirements of the rule of law, conflict with other important values of a legal system (justice, rationality, fairness, etc.). 
The task of the theoretical analysis of formalism is to try to find the best way to reconcile these values and this task cannot be realized only within a theory of legal reasoning and interpretation. When there is tension between these values, the question of how a judge should decide a case cannot be answered without having a conception of other issues. A wider theoretical analysis is needed that requires the theorist to explicate her conception about the nature of law, the authoritative force of law, the function of adjudication in a democratic society and the features of a virtuous judicial decision and find the place of formalism in this coherent theoretical framework.

The main standpoint here is that law is an authoritative normative system and judges are obligated to decide according to the prescriptions of law. They have to justify their decisions by relying on the facts of cases and reasons that are parts of the law. Formalism concentrates on the question how judges should justify their decisions and how they should interpret source-based law to reach the legally correct and right answer. However, judging the merits of this normative theory of adjudication requires us to take into consideration the special circumstances of decision-making, reasoning and interpretation in the field of law. When someone attempts to establish a correct theory about judicial decision-making, at least, the following factors should appear in the analysis. A normative theory of legal reasoning and interpretation should analyse the question of what kind of special practical guidance law provides and what kind of special obligation does it require from judges. This question can be explored by illuminating the concept of legal authority (Bódig 2007: 130). Formalism as a normative theory of adjudication cannot avoid elucidating this question, because law provides special reasons for action and decision, it has a special authoritative character. The theoretical implications of law's claim to authority on how judges should decide legal cases cannot be ignored.

The other important factor that has implications on a normative theory of adjudication is the question of the persons who has to interpret the law (Bódig 2007: 130-131). Making legal decisions is the responsibility of special legal institutions, namely courts and judges. The theory of formalism, when it explicates its main theses, should pay attention to the special institutional and personal features of adjudication. It has to take into account of the institutional and constitutional design of a legal system, for instance it has to explain the function and role of judicial institutions in democratic political communities, moreover the personal capacities and virtues of judges also should be the part of its explanation about the correct method of legal reasoning and interpretation.

My argument was that formalism is a necessary part of a legal system and adjudication. Committing ourselves to formalism sometimes entails that our decisions will not be just or fair or reasonable, all things considered. The justification of this judicial attitude or strategy requires us to contemplate not just the functions of adjudication and the features of a virtuous judicial decision, but also requires us to reveal the complex theory of the nature and function of law, too. Namely, behind the theory of a formalist adjudication we need a theory about the nature and function of law that should be explicated.

\section{REFERENCES}

Alexander, L. (1999): With Me It's All or Nothing: Formalism in Law and Morality. University of Chicago Law Review 66: 530-565, 531.

Alexander, L.-Sherwin, E. (2008): Demistifying Legal Reasoning. Cambridge, New York: Cambridge University Press, 133. 
Bencze, M. (2011): Elvek és gyakorlatok. Jogalkalmazási minták és problémák a birói itélkezésben (Principles and Practices. Decisional Patterns and Problems in Adjudication). Gondolat, Budapest.

Bencze, M.-Matzak, M.-Kühn, Z. (2010): Constitutions, EU Law and Judicial Strategies in the Czech Republic. Hungary and Poland. Journal of Public Policy 30: 81-99.

Blutman, L. (2010): Bírói jogalkalmazás és szöveghủ értelmezés (Adjudication and Textual Interpretation). Jogesetek Magyarázata 4: 94-104.

Bódig, M. (2004): A szabály és a jog. Egy kontingens fogalmi kapcsolat analitikai dimenziói (Rules and the Law. Analytical Dimensions of a Contingent Conceptual Relation). In: Szabó, M. (ed.): Regula Iuris. Szabály és/vagy norma a jogelméletben (Regula Iuris. Rule and/or Norm in Legal Theory). Miskolc: Bíbor 93-108.

Bódig, M. (2006): Egy hiányjelenség a jogban: a joghézag. (A Phenomenon of Deficiency in Law: Ambuigity.) Café Bábel 53: 33-42.

Bódig M. (2007): Legal Interpretation, Intentionalism and the Authority of Law. Acta Juridica Hungarica 48: 125-142.

Bódig, M.: Rules, Principles, and the Problem of the Limits of Legal Reasoning. Electronic copy available at: $\mathrm{http}: / /$ ssrn.com/abstract=1318638.

Dworkin, R. (1985): A Matter of Principle. Harvard University Press.

Dworkin, R. (1986): Law's Empire. Cambridge, London: The Belknap Press of Harvard University Press, 176-192.

Dworkin, R. (2011): Justice for Hedgehogs. Cambridge, London: The Belknap Press of Harvard University Press, 402.

Leiter, B. (1999): Positivism, Formalism, Realism. Legal Positivism in American Jurisprudence by Anthony Sebok. Columbia Law Review 99: 1138-1164.

Leiter, B.: Legal Formalism and Legal Realism: What is the Issue? Electronic copy available at: http://ssrn.com/abstract=1646110, 1.

Manning, J.F. (1999): Constitutional Structure and Statutory Formalism. The University of Chicago Law Review 66: 685-697.

Michelman, F. I. (1999): A Brief Anatomy of Adjudicative Rule-Formalism. University of Chicago Law Review 66: 934-942.

Moore, M. S. (1980-1981): The Semantics of Judging. Southern California Law Review 54: 151-294.

Posner, R. (1986-1987): Legal Formalism, Legal Realism, and the Interpretation of Statutes and the Constitution. Case Western Reverse Law Review 37: 179-217.

Raz, J. (2009): Between Authority and Interpretation. On the Theory of Law and Practical Reason. Oxford: Oxford University Press,

Schauer, F. (1988-1989): Formalism. Yale Law Journal 97: 509-548.

Schauer, F. (2009): Thinking Like a Lawyer. A New Introduction to Legal Reasoning. Cambridge, London: Harvard University Press, 29-35.

Schauer, F. (1991): Rules and the Rule of Law. Harvard Journal of Law and Public Policy 14: 645694. 651-657.

Schauer, F. (2004): The Limited Domain of the Law. Virginia Law Review 90: 1909-1956.

Solum, L. B. (2010): The Interpretation-Construction Distinction. Constitutional Commentary 27: 95-118.

Solum, L. B. (2003): Virtue Jurisprudence: A Virtue-Centered Theory of Judging. Research Paper No. 2003-4. In: Social Science Research Network electronic library at: http://ssrn.com/abstract id $=369940.184$.

Summers, R. S. (1992a): The Formal Character of Law. Cambridge Law Journal 51: 242-262. pp. 245-246.

Summers, R. (1992b): Essays on the Nature of Law and Legal Reasoning. Berlin: Duncker and Humblot, 141.

Tate, A. jr. (1975): The Justice Function of the Judge. Southern University Law Review 1: 250-265.

Weinrib, E. (1987-1988): Legal Formalism: On the Immanent Rationality of Law. Yale Law Journal 97: 949-1016. 